\title{
Jarosław Kundera
}

Uniwersytet Wrocławski

e-mail: jaroslaw.kundera@uwr.edu.pl

\section{METODY PRZEZWYCIEZŻENIA KRYZYSU W STREFIE EURO NA PRZYKLADZIE GRECJI I IRLANDII}

\section{METHODS TO OVERCOME THE CRISIS \\ IN THE EUROZONE FROM THE EXPERIENCE OF GREECE AND IRELAND}

DOI: $10.15611 / \mathrm{pn} .2018 .539 .10$

JEL Classification: $\mathrm{F}$

Streszczenie: Głównym celem artykułu jest analiza przyczyn kryzysu w strefie euro i metod podjętych w celu jego przezwyciężenia na podstawie doświadczeń krajów najbardziej dotkniętych kryzysem. Analiza dotychczasowych reform przeprowadzanych w strefie euro uwzględnia doświadczenia Grecji i Irlandii, dwu krajów z tzw. krajów PIGS znacznie różniących się pod względem otwartości zewnętrznej i udziału sektora publicznego w gospodarce. Chociaż kryzys w strefie euro zwalczano w tych krajach głównie klasycznymi metodami krótkookresowej interwencji, to efektywna polityka antykryzysowa wymagała również przeprowadzenia głębokich działań strukturalnych oraz skoordynowanej polityki gospodarczej w ramach UE.

Słowa kluczowe: kryzys gospodarczy w Grecji i Irlandii, dług publiczny, program oszczędnościowy.

Summary: The main goal of the paper is to distinguish the methods of overcoming the crisis in the Eurozone taking into considerations experiences of two members: Greece and Ireland. In times of the crisis, Greece and Ireland received economic aids from the EU and international institutions, which condition was the implementation of economic reforms and austerity programs. More successful overcoming of crisis in Ireland than in Greece derives from deeper structural reforms. However, a reform in the member states will not protect euro against further crises, if new rules of European integration are not introduced.

Keywords: economic crisis in Greece, economic crisis in Irealand, public debt, savings program. 


\section{Wstęp}

Kryzysy rzadko paraliżują całe gospodarki, jeżeli prowadzona jest w nich odpowiednia polityka gospodarcza, zwłaszcza monetarna i fiskalna. Ponieważ kryzys 2008 r. pokazywał błędy popełnione w polityce gospodarczej, stąd też działania antykryzysowe obejmowały m.in. przywrócenie prawidłowych relacji (policy mix) między polityką monetarną a fiskalną. Zadanie koordynacji polityki ekonomicznej kraje strefy euro mają jednak znacznie utrudnione ze względu na scentralizowaną politykę monetarną, prowadzoną przez Europejski Bank Centralny (EBC), której towarzyszą zdecentralizowane polityki fiskalne w krajach członkowskich. Ponieważ polityki fiskalne poddane są głównie kryteriom konwergencji, a w mniejszym stopniu podejmowaniu wspólnych działań antykryzysowych, powstaje problem ich prawidłowej koordynacji z polityką monetarną ECB.

Aby znaleźć skuteczną receptę na chorobę kryzysu w strefie euro i uniknąć tego typu załamań w przyszłości, należy przede wszystkim wyjaśnić przyczyny tego kryzysu. Po pierwsze, kryzys euro okazał się nie tyle kryzysem pieniądza i jego funkcji środka płatniczego, miernika wartości, czy nawet środka tezauryzacji, ile kryzysem długu publicznego. Niektóre kraje, takie jak Grecja, Portugalia, Hiszpania, Irlandia, Włochy, nadmiernie zadłużyły się, czemu sprzyjały niskie stopy procentowe w strefie euro oraz niska inflacja. Strefę euro stygmatyzowano więc jako obszar nadmiernego zadłużenia, stawiając przed jej członkami zadanie przywracania równowagi budżetowej i obniżki długu. Wzrost długu publicznego jest jednak wynikiem nie tylko decyzji ekonomicznych, ale przede wszystkim politycznych. Słabe rządy, niezdolne do reform, nie tylko nie podwyższają podatków, ale też nie redukują wydatków, traktując dług publiczny jako środek zdobycia wyborców i finansowania sektora publicznego.

Po drugie, o ile przed kryzysem euro doprowadziło do pewnej konwergencji w ramach UE i przepływu pieniądza z centrum Europy do krajów peryferyjnych, o tyle z drugiej strony stało się niejako ofiarą własnego sukcesu płynącego z uzyskania pozycji pieniądza światowego i drugiego po dolarze amerykańskim składnika rezerw. Kurs euro w stosunku do kursu dolara USA ustalono wyjściowo na poziomie 1,18 dol. za jedno euro, a następnie obniżono do 0,823 dol. za euro, później zaś stopniowo zwiększano do ponad 1,40 dol. za jedno euro. Chociaż w 2017 r. kurs euro ukształtował się na poziomie $1,20 \mathrm{w}$ stosunku do dol. USA, to kurs funta obniżył się o $40 \%$ wobec euro, kiedy po referendum Wielka Brytania rozpoczęła procedurę opuszczenia Wspólnoty. Ta aprecjacja euro uderzyła w eksport wielu członków strefy euro, np. eksport Grecji na rynki krajów trzecich czy w eksport Irlandii na rynek Wielkiej Brytanii. Kryzys w strefie euro ujawnił zresztą nierównowagę nie tylko w zewnętrznych obrotach krajów peryferyjnych, ale również wewnątrz UE, gdzie wykształciły się dwie grupy krajów: z nadwyżką w handlu zagranicznym (Niemcy, Holandia, Austria, Belgia) i kraje notujące deficyt w obrotach bieżących (Grecja, Hiszpania, Portugalia, Irlandia, Francja, Włochy). Rozbieżna tendencja wzrostu 
produktywności i płac spowodowała obniżenie konkurencyjności niektórych gospodarek, dlatego strefie euro zagrażają nie asymetryczne szoki, lecz brak dyscypliny płacowej, szczególnie w krajach peryferyjnych.

Po trzecie, kryzys euro wyjawia słabość instytucjonalną UE i jej ułomny mechanizm polityki ekonomicznej opartej na scentralizowanej polityce monetarnej i polityce fiskalnej pozostawionej w krajach członkowskich. O ile polityka monetarna EBC ma jasno określony cel utrzymania niskiej inflacji, o tyle przed polityką fiskalną postawiono zbyt wiele sprzecznych celów, np. utrzymanie dyscypliny fiskalnej, zewnętrznej równowagi i zrównoważonego wzrostu. Położenie nacisku na przywracanie równowagi budżetowej przyniosło oczywiście konsekwencje deflacyjne i niski wzrost gospodarczy. W UE brakuje natomiast struktury charakterystycznej dla państw federacyjnych, umożliwiającej działalność automatycznych stabilizatorów budżetu federalnego na linii rząd centralny a regiony. J. Sachs i Sala-i-Martin twierdzą, że budżet federalny USA amortyzuje spadek produkcji w jednym ze stanów o 1 dolara w wysokości $40 \%$ poprzez zmniejszone obciążenia podatkowe w tym stanie na rzecz budżetu centralnego o 36 centów i zwiększone wydatki budżetu federalnego na świadczenia socjalne o 4 centy [Sachs, Sala-i-Martin 1989]. Natomiast w UE budżet akumuluje jedynie około 1\% PKB krajów członkowskich, wskutek czego spadek dochodu w jednym z krajów strefy euro o 1 euro może co najwyżej redystrybuować dochody w wysokości 0,5 centa. Równocześnie najważniejszymi pozycjami w budżecie UE są polityka rolna oraz polityka regionalna, które nie działają jako mechaniczne stabilizatory.

Po czwarte, kryzys wynika z zapisów Traktatu Maastricht, dotyczących pozycji EBC, przed którym postawiono główne zadanie utrzymania stabilności cen. Brakuje tutaj zaś zobowiązania do podejmowania działań antykryzysowych, co więcej, zakazano udzielania przez EBC pożyczek na pokrycie deficytu lub jakichkolwiek innych kredytów instytucjom lub organom UE, rządom centralnym, władzom regionalnym, jak również nabywania bezpośrednio od nich papierów dłużnych [Traktat 2005]. Dopiero w fazie ostrego kryzysu zdecydowano o zmianie polityki EBC w kierunku poluzowania ilościowego (quatitative easing) i zakupie obligacji rządów krajów członkowskich na rynku wtórnym. Stąd nic dziwnego, że dzięki elastycznemu działaniu Systemu Rezerwy Federalnej gospodarka amerykańska uporała się szybciej z kryzysem: o ile PKB USA był o 10\% większy w 2015 niż w 2007 r., o tyle w strefie euro tylko o 0,6\% wyższy [Stiglitz 2016]. Pojawiły się także różnice w dynamice wzrostu między krajami UE: o ile gospodarka niemiecka urosła w ciągu ośmiu lat od kryzysu o 6,8\%, a Irlandię zalicza się obecnie do krajów najszybciej rozwijających się w Europie, o tyle gospodarka Grecji znajduje się ciągle w stagnacji.

Co o kryzysie mówi teoria integracji i czy błędna jest koncepcja integracji monetarnej? Należy podkreślić, iż teoria integracji monetarnej, tzw. optymalnego obszaru walutowego, określa kilka warunków, jakie powinny spełniać gospodarki, które mogą powoływać wspólną walutę. Zdaniem R. Mundella warunkiem koniecznym takiego obszaru jest wysoka mobilność czynników produkcji między 
partnerami, szczególnie siły roboczej, przy tym mobilność ta może być zastąpiona elastycznymi rynkami pracy [Mundell 1961]. McKinnon wskazuje, iż do integracji monetarnej najbardziej nadają się gospodarki otwarte o dużym udziale dóbr wymienialnych (eksportowanych i importowanych) w PKB, bo wtedy wydatki budżetowe mogą zastępować najpełniej działanie elastycznych kursów walutowych [McKinnon 1963]. P. Kenen mówi z kolei, iż wspólny pieniądz powinien obejmować gospodarki dobrze rozwinięte o zróżnicowanych strukturach produkcji i zróżnicowanym eksporcie, bo w gospodarkach takich nie zachodzą często zmiany terms of trade i maleje prawdopodobieństwo wystąpienia między nimi asymetrycznych szoków [Kenen 1969].

Jeśli oceniać poszczególne gospodarki z punktu widzenia spełnienia kryteriów optymalnego obszaru walutowego, to strefa euro nie powinna obejmować wszystkich krajów członkowskich, ale jej członkiem na pewno nie mogłaby zostać Grecja. Z tego punktu widzenia źródeł kryzysu należy szukać w decyzjach politycznych akceptujących w strefie euro kraje, które nie spełniały odpowiednich kryteriów, nie tylko tych określonych w Maastricht, ale przede wszystkim kryteriów realnych. Pewien błąd tkwił zapewne w nieprawidłowym rozłożeniu akcentów sławnego raportu Delorsa: One market. One money, w którym wskazano, że wspólna waluta jest niezbędnym warunkiem uzyskania wszystkich korzyści z jednego rynku europejskiego (obniżki kosztów transakcyjnych, przejrzystości cen, niskiej inflacji), zapominając, iż polityka monetarna to przede wszystkim polityka zrównoważonego wzrostu i jako taka musi być prawidłowo zharmonizowana z polityką fiskalną [Delors 1990]. Błędem było również to, że nie przygotowano żadnego funduszu interwencyjnego na wypadek kryzysu, przypomnijmy: fundusz taki - Europejski Fundusz Współpracy Walutowej - funkcjonował już w przypadku poprzedniczki euro - ECU (European Currency Unit) i akumulował 20\% rezerw wszystkich państw członkowskich.

\section{Kryzys euro w Grecji}

Za datę graniczną kryzysu w Grecji uważa się październik 2009 r., kiedy rząd grecki opublikował prawdziwe dane o zadłużeniu krajowym i poprosił Międzynarodowy Fundusz Walutowy (MFW) oraz kraje UE o pomoc finansową. Do tej pory Grecję postrzegano jako w miarę stabilną gospodarkę, stopy procentowe jej obligacji państwowych różniły się niewiele od oprocentowania na rynku niemieckim (50 punktów, 0,5\%). Rozmiar załamania i paniki na rynku finansowym Grecji pokazują rosnące spready po 2009 r., kiedy stopy procentowe dwuletnich obligacji w Grecji wzrosły z 4,15\% do 177,3\% w 2012 r.

Dług publiczny Grecji rósł w kolejnych latach z 113\% w stosunku do PKB w 2008 r. do 179\% w 2017 r. Ponieważ deficyt budżetowy utrzymywał się na poziomie o wiele wyższym niż wyznacza kryterium z Maastricht (15,2\% w 2009 r.), pojawił się problem jego bieżącego finansowania. Banki miały kłopoty z płynnością 
i kryzys finansowy w Grecji doprowadził wkrótce do ruiny gospodarkę realną: spadł poziom produkcji, konsumpcji prywatnej, inwestycji. W ciągu ośmiu lat od 2008 do 2015 r. w ujęciu statystycznym gospodarka skurczyła się o ponad jedną czwartą. Jak widać w tabeli 1, najgłębszy spadek PKB odnotowano: w 2010 r. o 4,9\%, w 2011 r. o 7,1\% i w 2012 r. o 6,4\%. Obniżenie PKB było konsekwencją głównie zmniejszenia się konsumpcji prywatnej o 25,6\% i konsumpcji publicznej o 31,4\%, a także inwestycji brutto, które zmniejszyły się w latach 2009-2013 o więcej niż $80 \%$. W okresie kryzysu nastąpiła znaczna korekta na rynku pracy. W latach 2008-2013 stopa bezrobocia wzrastała co roku o około $2 \%$ do ponad $25 \%$ całkowitej siły roboczej, wskutek czego z Grecji wyemigrowało 450 tys. osób.

Tabela1. Podstawowe wskaźniki makroekonomiczne Grecji w latach 2008-2017

\begin{tabular}{|c|c|c|c|c|c|c|c|c|c|c|}
\hline \multicolumn{11}{|c|}{ Roczna zmiana procentowa } \\
\hline Lata & 2008 & 2009 & 2010 & 2011 & 2012 & 2013 & 2014 & 2015 & 2016 & 2017 \\
\hline PKB & $-0,2$ & $-3,2$ & $-4,9$ & $-7,1$ & $-6,4$ & $-4,0$ & 0,5 & $-0,4$ & $-0,0$ & 1,0 \\
\hline $\begin{array}{l}\text { Konsumpcja } \\
\text { prywatna }\end{array}$ & 4,0 & $-1,3$ & $-6,2$ & $-7,7$ & $-9,1$ & $-6,7$ & 0,7 & 1,0 & 0,5 & \\
\hline $\begin{array}{l}\text { Konsumpcja } \\
\text { publiczna }\end{array}$ & $-2,1$ & 4,8 & $-7,2$ & $-8,5$ & $-9,0$ & $-4,9$ & $-4,0$ & 1,2 & & \\
\hline $\begin{array}{l}\text { Akumulacja kapitału } \\
\text { trwałego }\end{array}$ & $-6,7$ & $-15,2$ & $-15,0$ & $-19,6$ & $-19,2$ & $-5,9$ & $-4,6$ & $-0,2$ & 0,1 & \\
\hline Eksport & 3,0 & $-19,5$ & $-5,2$ & 0,3 & $-2,4$ & 1,8 & 4,1 & 5,2 & & \\
\hline Import & 3,3 & $-20,2$ & $-6,2$ & $-7,3$ & $-13,8$ & $-5,3$ & $-1,2$ & 2,2 & & \\
\hline Popyt krajowy & 0,8 & $-3,4$ & $-8,5$ & $-9,0$ & $-10,2$ & $-6,5$ & $-1,2$ & 2,3 & & \\
\hline Bezrobocie & 7,7 & 9,5 & 12,6 & 17,7 & 24,3 & 27,5 & 26,6 & 25,8 & 2,5 & \\
\hline $\begin{array}{l}\text { Jednostkowe koszty } \\
\text { pracy }\end{array}$ & $-7,1$ & $-7,2$ & $-0,1$ & $-1,8$ & $-6,2$ & $-6,5$ & $-1,9$ & 0,2 & & \\
\hline Realne koszty pracy & 2,2 & 4,3 & $-1,3$ & $-2,9$ & $-5,5$ & $-4,9$ & $-1,0$ & $-0,7$ & & \\
\hline $\begin{array}{l}\text { Zharmonizowany } \\
\text { wskaźnik cen } \\
\text { konsumpcyjnych }\end{array}$ & 4,2 & 1,3 & 4,7 & 3,1 & 1,0 & $-0,9$ & 0,8 & 0,5 & 0,3 & \\
\hline Terms of trade & 0,6 & $-3,4$ & 1,8 & $-0,6$ & $-1,0$ & 0,2 & $-0,1$ & 0,3 & & \\
\hline Bieżące saldo bilansu & $-17,9$ & $-14,3$ & $-12,8$ & $-11,7$ & $-5,3$ & $-2,3$ & 2,0 & $-1,5$ & 0,1 & \\
\hline $\begin{array}{l}\text { Saldo sektora } \\
\text { publicznego }\end{array}$ & $-9,8$ & $-15,8$ & $-10,7$ & $-9,5$ & $-9,0$ & $-13,5$ & $-2,5$ & 0,5 & 0,7 & \\
\hline $\begin{array}{l}\text { Saldo cykliczne } \\
\text { budżetu }\end{array}$ & $-10,6$ & $-15,2$ & $-8,4$ & $-5,2$ & $-3,2$ & $-7,5$ & 2,6 & 0,9 & 0,1 & \\
\hline $\begin{array}{l}\text { Deficyt strukturalny } \\
\text { budżetu }\end{array}$ & $-9,7$ & $-15,4$ & $-8,9$ & $-5,8$ & $-1,0$ & $-1,2$ & $-1,9$ & $-1,7$ & 0,7 & \\
\hline Dług publiczny brutto & 113,0 & 129,3 & 148,3 & 170,3 & 156,9 & 176,2 & 176,3 & 170,2 & 179 & \\
\hline
\end{tabular}

Źródło: [Bordell, La Vella 2017]. 
Nierównowadze wewnętrznej gospodarki Grecji towarzyszyła nierównowaga zewnętrzna: obniżeniu wartości importu towarzyszył spadek eksportu, stąd przez cały okres kryzysu utrzymywał się ujemny bilans handlowy. Na niekorzystną strukturę eksportu i importu Grecji nakładały się ujemne wskaźniki terms of trade. W związku z ujemnym bilansem handlowym wielu ekonomistów i polityków popierało koncepcję powrotu Grecji do waluty narodowej, ponieważ uważali, że elastyczny kurs narodowej waluty - drachmy poprawi warunki konkurencyjne greckiej gospodarki. Przeważały jednak opinie, że jeżeli Grecja wróci do waluty narodowej, to kraj wprowadzi politykę autarkii, wstrzyma spłatę zobowiązań, odgrodzi się od europejskiego rynku finansowego na wiele lat. Spadek wartości pieniądza przyniesie wszystkie negatywne efekty hiperinflacji w postaci obniżenia dochodów, ucieczki kapitału za granicę, fali bankructw banków i firm. O ile Grecja potrzebowała, zdaniem D. Grossa, pomocy gospodarczej w wysokości 400 mld euro, o tyle brak tej pomocy i niekontrolowane opuszczenie strefy euro obniżyłoby jej dochód narodowy o $50 \%$ i zwiększyłoby poziom długu do wysokości $400 \%$ w stosunku do PKB [UBS 2011].

W 2015 r. produkcja przestała w Grecji spadać, ale gospodarka nie weszła jeszcze na drogę zrównoważonego rozwoju. Ponieważ udział inwestycji w PKB Grecji osiągnął najniższy poziom od 50 lat, wzrost inwestycji stanowił jeden z głównych czynników ożywienia gospodarczego. W 2015 r. inwestycje w środki trwałe brutto zmniejszyły się jeszcze o $0,2 \%$, ale o odwróceniu niekorzystnego trendu świadczy wzrost krajowej konsumpcji o 1\% i konsumpcji publicznej o 1,2\% oraz zwiększenie zatrudnienia o $0,6 \%$. Ze względu na głęboki kryzys napływ bezpośrednich inwestycji zagranicznych (BIZ) do Grecji został prawie całkowicie zatrzymany po 2008 r., osiągając bardzo niski poziom $300 \mathrm{mln}$ dol. Obniżenie napływu BIZ wiązało się z kryzysem finansowym, zwiększonym ryzykiem inwestycyjnym, spadkiem konkurencyjności gospodarki. Chociaż Grecja zalicza się do grupy krajów rozwiniętych, została sklasyfikowana na 100 pozycji pod względem konkurencyjności w 2012 r.; ustępując w rankingu takim krajom, jak: Rumunia, Bułgaria i Serbia.

Ponieważ Grecja nie była w stanie spłacać samodzielnie zaciągniętych kredytów i obsługiwać na bieżąco swojego długu, dlatego też zwróciła się o pomoc finansową do MFW, Europejskiego Banku Centralnego i partnerów ze strefy euro. Skala uzyskanej pomocy była ogromna: w sumie Grecja otrzymała w postaci redukcji zadłużenia, kredytów, subwencji 466 mld euro. W ramach pierwszego programu dostosowań gospodarczych w 2010 r. udzielono Grecji pożyczki w wysokości 110 mld euro. Drugi program dostosowań gospodarczych w 2012 r. obejmował pakiet pożyczkowy w wysokości 130 mld euro. Trzeci program pomocy dla Grecji rozpoczął się w 2015 r. i obejmował pożyczki finansowe w wysokości $86 \mathrm{mld}$ euro. W 2015 r. w ramach Europejskiego Instrumentu Stabilności Finansowej Grecja otrzymała 130,9 mld euro, dwustronne kredyty wynosiły 52,9 mld euro, w tym same Niemcy - największy wierzyciel Grecji - udzieliły w sumie pożyczek i dokonały redukcji długów w wysokości 69,6 mld [The Wall Street 2015]. Jak się oblicza, 
na dziesięć euro pomocy wysłane do Grecji, dziewięć euro było przeznaczone na spłatę zobowiązań.

Warunkiem udzielenia pomocy Grecji była realizacja programu reform, w tym programu oszczędności poprzez zmniejszenie finansowania nieefektywnego sektora publicznego. Na przykład greckie koleje miały przychody w wysokości $100 \mathrm{mln}$ euro, podczas gdy na same płace wydano $400 \mathrm{mln}$ euro, stąd rząd corocznie finansował koleje państwowe w wysokości $300 \mathrm{mln}$ euro [Newsweek 2013]. W związku z restrukturyzacją sektora państwowego bezrobocie w Grecji zwiększyło się do 1,4 mln osób bez pracy na 3,6 mln pracowników, przy czym największy problem z uzyskaniem pracy miała młodzież i kobiety, a w grupie wiekowej 15-24 lat bezrobocie wzrosło do 58,8\% [Rzeczpospolita 2013]. Ponieważ Grecja przed kryzysem miała najwyższy poziom regulacji rynku pracy w Europie, reformy nakierowano na uelastycznienie rynku pracy poprzez m.in. takie działania, jak: obniżenie płacy minimalnej, przedłużenie zatrudnienia na okres próbny, reorganizacja zasad przeprowadzania zwolnien grupowych, ułatwienia w zatrudnianiu w niepełnym wymiarze godzin, eliminowanie barier w dostępie do niektórych zawodów (farmaceuci, prawnicy, architekci, notariusze). Płace minimalne obniżono do niskiego poziomu 511 euro dla pracowników bez doświadczenia poniżej 25 lat i 586 euro dla pracowników powyżej 25 lat [OECD 2016].

Program oszczędnościowy nałożony na Grecję przypominał programy dostosowawcze Banku Światowego, który wymagał od zadłużonych krajów zmniejszania roli rządu w gospodarce, cięć wydatków budżetu, prywatyzacji, zmniejszenia konsumpcji. Działania antykryzysowe w Grecji zależały więc w dużej mierze od reformy podatkowej w zakresie podatków bezpośrednich i pośrednich, poszerzenia bazy podatkowej, uszczelnienia systemu podatków; koszt uchylania się od płacenia podatków szacowano na ponad $20 \mathrm{mld}$ euro rocznie [European economic]. Grecki rząd zwiększył stawki VAT z $19 \%$ do $23 \%$ na wszystkie produkty z wyjątkiem artykułów spożywczych. Utrzymano obniżone stawki VAT w wysokości 5\%, 9\% lub $16 \%$ tylko na niektórych wyspach greckich. Wzrosły podatki akcyzowe na alkohol, tytoń i benzynę. Podniesiono podatki dotyczące osób najbogatszych do $42 \%$ powyżej dochodu 42000 euro. Tylko rolnicy płacą w Grecji 13\% podatku dochodowego. Grecja przeprowadziła także reformę systemu ubezpieczeń społecznych (wydatki na emerytury przekroczyły $17 \%$ PKB); nowe zasady podwyższały stopniowo wiek emerytalny. Do 2023 r. emerytury będą płatne tylko od 67. roku życia.

Jak wykazały doświadczenia austerity program, jego wdrożenie w okresie głębokiej depresji działa z opóźnieniem w gospodarce greckiej i dopiero od stycznia 2015 do stycznia 2016 r. produkcja podniosła się o 7,4\%, w pierwszym kwartale 2017 r. wzrosła o 1,8\%, a w całym roku PKB powiększyła się o 1\%. Powrotu zaufania inwestorów do greckiej gospodarki spodziewano się po spłacie kredytu do EBC w sierpniu 2015 r. i dzięki sfinalizowaniu trzeciego bailoutu. W kwietniu 2015 r. rząd Grecji wydał 5-letnie obligacje o wartości około 3 mld euro, a popyt na te obligacje przekroczył sześciokrotnie ofertę sprzedaży - ponad 20 mld, natomiast 
oprocentowanie obligacji spadło do 4,95\%. Wzrost gospodarczy w 2017 r. zmniejszył poziom bezrobocie do 21,7\%. O ile w 2015 r. przyjechało do Grecji 23,5 mln turystów, w 2016 r. było ich $27,5 \mathrm{mln}$, w 2017 r. ponad $30 \mathrm{mln}$, stąd wpływy z turystki w wysokości 14,2 mld euro tworzą najwięcej, bo 24\%, PKB i 8 na 10 nowych stanowisk pracy [The Guardian 2017]. Utrzymujący się poziom bezrobocia i reformy rynku pracy wywarły presję na obniżenie płac, wobec czego w latach 2008-2015 koszty siły roboczej w Grecji spadły średnio o 30\%. Niższe koszty pracy służyły do odzyskania konkurencyjności firm szczególnie małych i średnich i dzięki obniżce kosztów grecki eksport wzrósł o 4,1\% w 2014 r. i o 5,2\% i w 2015 r. Jednakże udział handlu zagranicznego w PKB Grecji to tylko $34,1 \%$ PKB, natomiast w Irlandii ten udział wynosi 100,8\%. Gospodarka Grecji nie jest zatem dobrze zintegrowana z międzynarodowym łańcuchem dostaw i, odwrotnie niż w przypadku Irlandii, wzrost wywozu trudniej tutaj osiągnąć szczególnie wobec spadku przewozów morskich, które odpowiadają za 20\% eksportu [OECD 2016].

Pomimo wzrostu dochodów z turystyki reformy w Grecji muszą być konsekwentnie kontynuowane zarówno w dziedzinie finansów, jak i w gospodarce realnej. Dla poprawy efektywności funkcjonowania sektora publicznego przeprowadza się stopniową prywatyzację, a uzyskane wpływy ze sprzedaży państwowych przedsiębiorstw, ziemi, portów to około 50 mld euro. Aby zmniejszyć nadmierny dług, trzeba w pierwszej kolejności dążyć do równowagi budżetowej i dobrym sygnałem jest uzyskana nadwyżka salda sektora publicznego w 2016 r. w wysokości 0,7\%. Działania propodażowe Grecji muszą obejmować: zwiększenie produktywności, inwestycji, konkurencji, zmianę struktury gospodarczej w kierunku większej dywersyfikacji produkcji i wytwarzania dóbr o wyższej wartości dodanej. Eksperci OECD, analizując politykę rządową w okresie kryzysu, konkludują, że w Grecji nadmierne reformy podjęto na rynku pracy, natomiast powolne są zmiany na rynku produktów, obciążeń regulacyjnych i krajowych monopoli. Jak się ocenia, udane reformy na rynku produktów i usług mogą wygenerować wzrost gospodarczy w wysokości 13,5\% PKB [OECD 2016]. Możliwości przywrócenia szybkiego wzrostu w Grecji zależą również od pozytywnej oceny reform przez zagraniczny kapitał i napływu inwestycji bezpośrednich. Stopniowe rozluźnienie kontroli wywozu kapitału przywróciło zaufanie rynków finansowych, ale dotychczasowe reformy przyczyniły się w umiarkowanym stopniu do przyciągnięcia zagranicznych inwestycji w wysokości 1140 mld dol. w 2015 r. i 3125 mld dol. w 2016 r. Zagrożenie dla podjętych reform stanowi olbrzymi napływ uchodźców z Syrii, którzy mogą zdestabilizować sytuację Grecji.

\section{Kryzys euro w Irlandii}

Przed kryzysem podaż pieniądza (M3) zwiększyła się w Irlandii o ponad 540\% i dzięki tanim pożyczkom wzrósł popyt m.in. na nowe domy, co podniosło ich ceny od 3 do 6 razy [Eurostat 2009]. W czasie boomu gospodarczego około 15\% irlandz- 
kiej siły roboczej było zatrudnionej w sektorze budownictwa, a 20\% dochodów budżetowych państwa pochodziło z podatku od nieruchomości. Wiele projektów budowlanych finansowały banki, co w końcu doprowadziło wzrostu ich zadłużenia zagranicznego z 15 miliardów euro do 110 mld w latach 2004-2008, stąd kiedy pękła bańka na rynku nieruchomości, nastąpił spadek wartości domów i utrata wielu kredytów [Eurostat 2013].

Należy zauważyć, że Irlandia była szczególnie narażona na zewnętrzne szoki, wziąwszy pod uwagę duży udział eksportu w PKB i integrację produkcji w skali globalnej, gdzie sektor finansowy był powiązany z siecią międzynarodowych banków, a największy bank Irlandii (Anglo Irish Bank) rozwijał się przed kryzysem średnio o $36 \%$ rocznie, zwiększając swój udział w krajowym rynku z 3\% do $18 \%$. Kiedy po 2009 r. właściciele nie mogli sprzedać domów i spłacić kredytów, instytucje finansowe działające w Irlandii wstrzymały akcję kredytową, ograniczając pożyczki dla gospodarki. W obliczu bankructwa banków i niemożności rolowania długu rząd irlandzki zapowiedział gwarancję wypłacalności głównych banków irlandzkich i znacjonalizował Anglo Irish Bank, którego zobowiązania wynosiły 20\% PKB. W budżecie irlandzkim w 2010 r. powstał wskutek tego niespotykany poziom deficytu budżetowego w wysokości 33,1\% w stosunku do PKB.

Po pęknięciu bańki spekulacyjnej gospodarka Irlandii przeszła bezprecedensowe załamanie w latach 2008-2010: PKB zmniejszył się o 10,4\%, konsumpcja o 9,5\%, spadły inwestycje w środki trwałe o $52,8 \%$ (tabela 2 ). W poszukiwaniu oszczędności spadło spożycie publiczne, konsumpcja prywatna, inwestycje, co przyniosło podwojenie bezrobocia z $6,3 \%$ do 13,7\%. Wzrost bezrobocia skłonił 34500 ludzi do opuszczenia kraju w latach 2009-2010, przy czym 27700 z nich było obywatelami Irlandii. W 2013 r. z Irlandii wyemigrowało kolejne 75 tys. mieszkańców. Presja na obniżenie płac przyniosła spadek realnych kosztów pracy w latach 2009-2014 o w sumie $14,5 \%$. Co gorsza, wysoka inflacja, która towarzyszyła boomowi gospodarczemu Irlandii, zamieniała się w deflację.

Załamanie gospodarcze okazało się tak głębokie, że Irlandia poprosiła o pomoc finansową międzynarodowe instytucje i w $2010 \mathrm{r}$. MFW oraz UE zgodziły się na udzielenie pomocy w wysokości 85 mld euro, z tego 22,5 mld euro pochodziło z Europejskiego Mechanizm Stabilności Finansowej (EFSM). W zamian za pomoc finansową rząd irlandzki wprowadził oszczędności (w sumie 15 mld euro) w ciągu czterech lat poprzez: zmniejszenie wydatków na ochronę zdrowia, wprowadzenie $7,5 \%$ opłaty od płac funkcjonariuszy publicznych, obniżkę emerytur i stypendiów, obniżenie zatrudnienia pracowników w administracji o 24750 osób, obniżenie kosztów ich wynagrodzeń o 1,2 mld euro, cięcia płac minimalnych, $2 \%$ wzrost podatku od wartości dodanej. Ale kiedy w 2015 r. deficyt spadł poniżej poziomu z Maastricht, rząd Irlandii zdecydował się na obniżki podatków i wzrost wydatków. Niskie podatki miały wpływ na to, że Irlandia najszybciej z krajów dotkniętych kryzysem zatrzymała spadek produkcji: PKB wzrósł o 5,1\% w $2016 \mathrm{r}$. W Irlandii podatek CIT to zaledwie $12,5 \%$, należy do najniższych w UE, tymczasem stawka tego podatku 
Tabela 2. Wskaźniki makroekonomiczne Irlandii w latach 2008-2017

\begin{tabular}{|l|r|r|r|r|r|r|r|r|r|r|}
\hline \multicolumn{1}{|c|}{ Lata } & 2008 & 2009 & 2010 & 2011 & 2012 & 2013 & 2014 & 2015 & 2016 & 2017 \\
\hline PKB & $-3,0$ & $-7,0$ & $-0,4$ & 1,1 & 1,1 & 2,3 & 4,8 & 3,6 & 5,1 & 3,7 \\
\hline $\begin{array}{l}\text { Konsumpcja } \\
\text { prywatna }\end{array}$ & $-1,4$ & $-7,2$ & $-0,9$ & $-2,4$ & $-1,1$ & 0,5 & 2,2 & 3,6 & 2,2 & \\
\hline Spożycie publiczne & 1,2 & $-3,7$ & $-3,1$ & $-3,6$ & $-1,0$ & $-2,1$ & 5,3 & 2,8 & & \\
\hline $\begin{array}{l}\text { Inwestycje trwałe } \\
\text { brutto }\end{array}$ & $-10,1$ & $-28,8$ & $-25,1$ & $-10,5$ & 0,6 & 4,2 & 8,6 & 9,8 & 8,5 & \\
\hline Eksport & $-1,1$ & $-4,2$ & 6,3 & 4,5 & 3,8 & 4,3 & 12,7 & 5,6 & 2,4 & 6,3 \\
\hline Import & $-3,0$ & $-9,3$ & 2,7 & 1,6 & 2,6 & 3,1 & 12,2 & 6,0 & 10,4 & 8,8 \\
\hline Stopa bezrobocia & 6,3 & 11,9 & 13,7 & 14,4 & 14,3 & 13,6 & 11,1 & 9,6 & 7,9 & 6,9 \\
\hline $\begin{array}{l}\text { Jednostkowe koszty } \\
\text { pracy }\end{array}$ & 7,5 & $-2,4$ & $-6,9$ & $-3,1$ & $-1,2$ & $-0,8$ & $-3,9$ & 0,4 & & \\
\hline Realne koszty pracy & 10,1 & 1,7 & $-4,6$ & $-2,1$ & $-1,9$ & $-2,0$ & $-3,9$ & 1,2 & & \\
\hline $\begin{array}{l}\text { Wskaźnik cen } \\
\text { konsumpcyjnych }\end{array}$ & 3,1 & $-1,7$ & $-1,6$ & 1,1 & 0,7 & 1,2 & 0,3 & 0,0 & $-0,2$ & 0,8 \\
\hline Terms of trade & $-5,5$ & 6,1 & $-3,4$ & $-4,9$ & 0,8 & 0,0 & & & & \\
\hline $\begin{array}{l}\text { Bieżące saldo } \\
\text { handlowe }\end{array}$ & $-5,6$ & $-2,9$ & 0,5 & 0,7 & 1,5 & 1,8 & 5,0 & 5,7 & 4,7 & 4,1 \\
\hline Deficyt budżetowy & $-7,3$ & $-14,2$ & $-31,3$ & $-10,3$ & $-8,6$ & $-7,3$ & $-4,0$ & $-2,8$ & $-1,9$ & $-0,7$ \\
\hline Dług publiczny & 44,3 & 65,2 & 99,9 & 108,0 & 121,0 & 110,8 & 110,3 & 105,0 & 78,8 & 75,8 \\
\hline
\end{tabular}

Źródło: [European Commission 2015].

w Grecji wynosi $25 \%$. Podatki nałożony na firmy zagraniczne były w Irlandii tak niskie, że Komisja Europejska zasugerowała rządowi w 2016 r. odzyskanie 13 mld euro niezapłaconych podatków od amerykańskiej firmy Apple.

Ze względu na niską inflację oraz zmniejszenie rzeczywistych kosztów pracy Irlandia poprawiła konkurencyjność swojego przemysłu i usług. Po 2014 r. nastąpiło odzyskiwanie równowagi zarówno zewnętrznej, jak i w obszarze finansów publicznych, gdzie deficyt budżetowy zmniejszył się do -0,7\% w 2017 r. Wydaje się, że dwa czynniki przyczyniły się najbardziej do przezwyciężenia kryzysu w Irlandii: wzrost eksportu i wzrost inwestycji. Wzrost eksportu pochodził głównie z sektorów produkcji lekarstw, programów komputerowych i usług, znanych specjalizacji gospodarki irlandzkiej. W efekcie eksport Irlandii wzrósł o 6,3\% w 2010 r., o 12,7\% we 2014 r. oraz o 5,3\% w 2016 r., co przyczyniło się do uzyskania dodatniego salda obrotów, zwłaszcza dzięki eksportowi towarów zaawansowych technologicznie. W latach 2014 i 2015 nastąpił też wzrost inwestycji w Irlandii - odpowiednio o $8,6 \%$ i $9,7 \%$ i w wyniku ożywienia gospodarczego stopa bezrobocia spadła do $6,9 \%$ w 2017 r. Poprawa sytuacji gospodarczej w Irlandii zatrzymała falę emigracji, a w ostatnim czasie przeważała imigracja. 
W sumie polityka antykryzysowa w Irlandii różniła się od tej zastosowanej w Grecji, ponieważ odpowiedziała ona głównie na kryzys metodami gospodarki liberalnej. Podczas kryzysu Irlandia przeprowadziła istotną restrukturyzację gospodarki, natomiast w Grecji proces ten następuje z dużymi oporami. Szybciej zrestrukturyzowano banki w Irlandii niż w Grecji, bardziej elastyczne reformy przeprowadzono na rynku pracy. O ile Grecja czeka na kolejne transze pomocy, rozważa restrukturyzację długu, o tyle Irlandia wprowadziła skutecznie program oszczędnościowy, naprawę sektora bankowego i finansów publicznych. Popyt wewnętrzny został odbudowany, a wzrost eksportu wyprzedzał wzrost importu. Irlandia była pierwszym członkiem strefy euro, który oficjalnie wyszedł spod kurateli KE, EBC i MFW. Zasługą rządu Irlandii było wynegocjowane ze związkami zawodowymi w Croke Park porozumienie, które zwiększyło wydajność i elastyczność rynku pracy i zamroziło podwyżki płac. W zamian za niepodnoszenie podatków zrezygnowano z masowych zwolnień pracowników. Szybszy wzrost wydajności niż płac przyniósł poprawę konkurencyjności gospodarki Irlandii i wzrost eksportu. Paradoksalnie Irlandia - z kraju UE dotkniętego najcięższym kryzysem - powróciła do grona najszybciej rozwijających się gospodarek. Przykład Irlandii, gdzie PKB wzrósł w latach 2016-2017 o 8,8\%, to jest najszybciej w UE, pokazuje, że elastyczne zarządzanie i skuteczna transformacja pozwalają na szybkie przezwyciężenie kryzysu.

\section{Perspektywy strefy euro}

Po dziesięciu latach od rozpoczęcia kryzysu kraje strefy euro weszły na ścieżkę szybkiego wzrostu gospodarczego dzięki wewnętrznej dewaluacji i głębokim reformom strukturalnym. W UE powstają jednak nowe sytuacje konfliktowe na tle kryzysu uchodźców i brexitu, stąd przed strefą euro rysują się różne scenariusze jej dalszej ewolucji: od jej rozwiązania po reformę całej Wspólnoty. Najwięcej zwolenników zyskuje koncepcja tzw. Europy dwu prędkości, tj. ściślejszej integracji w strefie euro. W myśl tej koncepcji jądrem integracji europejskiej stanie się strefa euro, natomiast inne kraje UE pozostaną partnerami drugiej prędkości. Nie wiadomo, jaki aparat instytucjonalny powoła „Europa pierwszej prędkości”, jak zorganizowane zostaną stosunki strefy euro z pozostałymi partnerami UE. Nie przesądzając o możliwych rozwiązaniach, wskazuje się tutaj na potrzebę zmian w kierunku sfederalizowanej Europy ze ścisłą koordynacją polityki ekonomicznej i wspólną polityką obrony, powołania wspólnego ministra finansów, odrębnego budżetu strefy euro, powołania funduszu umożliwiającego działanie automatycznych stabilizatorów, unii bankowej i wzmocnienie nadzoru bankowego. Ograniczenie pierwszej prędkości do strefy euro oznaczałoby jednak, że w jednej, bogatszej części UE będą przepływały intensywnie towary i kapitały, będą się utrzymywały niskie stopy procentowe i niska inflacja, a w drugiej, peryferyjnej, o niższej stabilności, przepływy inwestycji, dóbr i usług mogłyby być mniej intensywne. Poza tym przy realizacji tej koncepcji 
powstaje groźba, czy członkowie UE pozostający poza strefą euro nie poszliby za przykładem Wielkiej Brytanii i nie zdecydowaliby się na jej opuszczenie.

\section{Zakończenie}

Kryzys w strefie euro okazał się najgłębszym szokiem gospodarczym od czasu ustanowienia UE. Jego ujemne konsekwencje ujawniły się szczególnie w tzw. krajach PIGS, m.in. w Grecji i Irlandii, które w czasie kryzysu uzyskały pomoc gospodarczą od UE i instytucji międzynarodowych pod warunkiem wdrożenia reform gospodarczych i programów oszczędnościowych. Doświadczenia tych krajów pokazują, że podstawowym narzędziem przezwyciężenia kryzysu jest wewnętrzna dewaluacja, obejmująca redukcję wydatków sektora publicznego, płac i podwyżkę podatków.

Irlandia znacznie szybciej przezwyciężyła kryzys niż Grecja, co wynika z reform strukturalnych w kierunku wzrostu eksportu, uelastycznienia rynków pracy, większej konkurencyjności i wiarygodności ze strony rynków finansowych. Reformy w samych krajach członkowskich nie ochronią jednak strefy euro przed dalszymi kryzysami, jeśli nie wprowadzi ona również nowych reguł integracji europejskiej. Chodzi tutaj głównie o zmiany instytucjonalne UE, które zagwarantują właściwą koordynację między polityką monetarną ECB a politykami fiskalnymi krajów członkowskich, w tym wzmocnienie nadzoru bankowego w ramach unii bankowej, powołanie funduszu umożliwiającego działanie automatycznych stabilizatorów.

\section{Literatura}

Bordell J.V., La Vella S., 2017, Key macro-economic indicators for Cyprus, Greece, Portugal and Ireland, European Parliament.

Delors J., 1990, One market, one money. An evaluation of the potential benefits and costs of forming an economic and monetary union, European Economy, 44, October.

European Commission 2015.

European economic forecast - autumn 2011, European Commission.

Eurostat, 2009, European Business. Facts and Figures, Bruxelles.

Eurostat, 2013, European Economy, European Commission, Luxembourg.

International New York Times, Wednesday, 8 July 2015.

Kenen P.B., 1969, The Theory of Optimum Currency Areas: An Eclectic View, [w:] Mundell R., Swoboda A. (eds.), Monetary Problems of the International Economy, University of Chicago Press, Chicago.

McKinnon R.I., 1963, Optimum currency areas, American Economic Review, no. 4.

Mundell R.A., 1961, A Theory of optimum currency areas, American Economic Review, no. 4.

Newsweek, 18 December 2013.

OECD, 2016, Economic Surveys. Greece, March.

OECD, 2017, Country statistical profile, Greece.

Rzeczpospolita 2013.

Sachs J., Sala-i-Martin X., 1989, Federal Fiscal Policy and Optimum Currency Areas, Harvard University Working Paper, Cambridge. 
Stiglitz J.E, 2016, The Euro and its Threat to the Future of Europe, W.W. Norton, New York - London. The Economist, 9-15 September 2017.

The Guardian Weekly, 7-13 July 2017.

The Observer, Eurozone crisis, Saturday, 13 August 2016.

The Wall Street Journal, Tuesday, 7 July 2015.

Traktat o Unii Europejskiej, Tekst ujednolicony, art. 101, 105, Urząd Komitetu Integracji Europejskiej, Warszawa 2005.

UBS Quantifies Cost of Euro Break Up, 2011, http://blogs.wsj.com/economics/2011/09/07 (26.11. 2017). 